\section{Qualitative analysis of the diet of a probabilistic sample of schoolchildren from Florianópolis, Santa Catarina State, Brazil, using the Previous Day Food Questionnaire}

\author{
Análise qualitativa da dieta de amostra \\ probabilística de escolares de Florianópolis, \\ Santa Catarina, Brasil, com o uso do Questionário \\ Alimentar do Dia Anterior
}

\author{
Maria Alice Altenburg de Assis 1 \\ Maria Cristina Marino Calvo 1 \\ Emil Kupek 1 \\ Francisco de Assis Guedes de Vasconcelos 1 \\ Vanessa Caroline Campos 1 \\ Manuella Machado 1 \\ Filipe Ferreira da Costa 1 \\ Dalton Francisco de Andrade 2
}

${ }^{1}$ Centro de Ciências da Saúde, Universidade Federal de Santa Catarina, Florianópolis, Brasil. 2 Departamento de Informática e Estatística, Universidade Federal de Santa Catarina Florianópolis, Brasil.

Correspondence M. A. A. de Assis Departamento de Nutrição, Centro de Ciências da Saúde, Universidade Federal de Santa Catarina.

Campus Universitário Trindade, Florianópolis, SC 88040-900, Brasil. massis@ccs.ufsc.br
Abstract

A qualitative evaluation of the diet of a probabilistic sample of 7-10 year old schoolchildren ( $n=$ 1,232) from Florianópolis (southern Brazil) was carried out by analyzing compliance with recommendations from the Brazilian Food Guidelines. The strengths and limitations of the Previous Day Food Questionnaire (PDFQ) are also presented. Frequencies of intake were defined as how many times per day the food group was reported on the PDFQ. The percentages of schoolchildren who met the minimum recommendations and who ate foods that were not recommended in the guidelines were compared for boys versus girls, private versus public school and by family income level. Although most of the children complied with the guidelines regarding consumption of meat/fish, dry beans, sweets, and eating three meals and two snacks, only $6.5 \%$ of the children met the recommendations for cereals, and 15\% for fruit and vegetables. The PDFQ was confirmed as a practical and cost-effective method for the evaluation of compliance with health promotion targets.

Diet Surveys; Food Habits; Questionnaires; Students

\section{Introduction}

The prevalence of overweight in 6-9 year old Brazilian children tripled over two decades (from $4.9 \%$ in 1974 to $17.4 \%$ in 1997) 1 . The evidence of major changes in dietary patterns and low physical activity levels has also been documented across the country 2,3 . To cope with these rapid changes, several programs promoting healthy lifestyles were launched in schools, which have been the preferred settings for this type of intervention in Brazil. The programs have focused on quality improvements in school meals, the regulation of foods offered in school canteens, and educational messages to encourage healthy eating and physical activity 4,5,6.

The above developments highlighted the need for a suitable diet assessment method to examine the dietary factors contributing to the increase in obesity among Brazilian children, as well as to monitor these trends and evaluate the effectiveness of interventions aimed at reducing obesity. It is well recognized that such a method should take into account children's cognitive abilities and their literacy levels, as well as local food customs and the recommendations for a healthy diet 7 . It is also important to note that simpler alternatives such as structured questionnaires are regarded as practical, feasible and cost effective mechanisms for epidemiological studies, as well as for the evaluation of school and community programs 8,9 . 
The Previous Day Food Questionnaire (PDFQ-3) was developed to address the above issues for schoolchildren. The questionnaire has been submitted to three validation studies $10,11,12,13$. Its third version 13 was employed in two large scale studies conducted in Florianópolis (the capital of Santa Catarina State) and eight other cities in the same state. These studies assessed the prevalence of overweight, eating and physical activity patterns of 7 to 14 year old schoolchildren, and the compliance of schools with the implementation of a government law regulating the commercialization of soft drinks and high-fat ready-to-eat snacks at school canteens 14

In this article, we analyze the data from the study conducted in Florianópolis in 2007 to present food intake recalled by 7-10 years old schoolchildren using the PDFQ-3, compare the results with the current recommendations in the Brazilian food guidelines 15 and report the daily frequencies of intake of high fat ready-to-eat snacks and soft drinks in light of local policies that restrict their availability in schools 14 . Finally we discuss the strengths and limitations of the PDFQ in epidemiological studies and point to future developments for the questionnaire.

\section{Methods}

\section{Subjects}

A cross-sectional study with a probabilistic sample of 7-10 year old schoolchildren from 2nd to 7 th grades of elementary school was conducted from March to October 2007 in the city of Florianópolis (Southern Brazil). The city has a population of 408,163 inhabitants 16 , life expectancy at birth is 76.6 years old 17 and the infant mortality rate is $8.03 / 1,000$ live births 18 . In 2007 , the reference year for the sample estimate, 26,269 students aged 7-10 years old were enrolled in 121 schools (81 public schools and 40 private schools). The sample size of 1,100 children was estimated for this study, assuming the $22.1 \%$ prevalence of overweight 19 with a margin of error of $4 \%$ around the point estimates and taking into account stratification and cluster effects. As a $10 \%$ non-response rate was expected, the total sample increased to 1,210 children. The study used a two-stage probabilistic cluster sampling design. In the first stage, the existing 121 elementary schools were stratified into four strata according to two geographic areas and type of schools (public and private). Within each stratum, schools were randomly selected with equal probability. In the second stage, children from each of the selected schools were randomly chosen with equal probability. One private school declined to participate and was replaced by another private school located in the same geographic area. The final sample included 1,232 children from 17 schools (950 children from 11 public schools and 282 children from 6 private schools). The children who refused to participate or who did not have parental consent were replaced by others from the same age range, living in the same geographic area and studying in the same school. The final number of children was slightly higher than the estimated because of a lower than expected proportion of incomplete data obtained. The data were weighted according to the respondents' probability of being selected and took into account the population density of schoolchildren in the stratified sample design. The sample weight was used for the prevalence estimates and included 95\% confidence intervals.

The information gathered in the study included anthropometric data (height; weight; triceps, subscapular, suprailiac and medial leg skinfolds; arm, waist and hip circumferences) and two questionnaires. The first one was the PDFQ - an illustrated questionnaire for children used to obtain information about physical activities and food consumption on the previous day. The second questionnaire targeted the parents and asked about their anthropometric and socio-demographic characteristics. Data were collected by trained researchers in each school, who performed the anthropometric measurements and administered the PDFQ following standardized protocols. The present analysis focuses on meals, snacks and food consumption recalled by the PDFQ.

The parents gave written informed consent for their child's participation in the study which received approval from the Committee on $\mathrm{Hu}$ man Studies at the Federal University of Santa Catarina.

\section{Food assessment}

The intake of food and beverages was assessed using the PDFQ-3, previously validated in a sample of 6-11 year old schoolchildren, through direct observation of the food eaten on the previous day as gold standard. Analysis indicated high sensitivity and specificity for the majority of food items 13 . More details on the development, design and administration of the PDFQ have been described elsewhere ${ }^{13}$. In short, it is an illustrated questionnaire, consisting of a single day recall procedure with six daily eating events ordered chronologically (breakfast, mid-morning snack, 
lunch, afternoon snack, dinner and evening snack). Each eating event is illustrated with 21 selected foods items or food groups (dry beans, rice, milk, coffee with milk, chocolate flavoured milk, cheese, yoghurt, beef or poultry, pasta, bread or crackers, french fries, pizza or hamburger, leafy vegetables, starchy vegetables, vegetable soup, fruits, sweets, chips, fish/sea foods, soft drinks and fruit juices). The foods and food groups were chosen to take into account the foods of children at the school age, including those presented in the school menus 20 (Figure 1).

The PDFQ was administered as a supervised classroom exercise by a trained researcher following a standardized protocol. Five researchers participated in training sessions and pilot studies conducted in three schools not included in the main study, in order to ensure the standardization of procedures for application of the questionnaire and so that they might familiarize themselves with the questions commonly posed by children. In each school, the study participants were grouped in a classroom according to their school grade. The class teacher introduced the researchers to the pupils and instructed them to keep silence, to give true responses to the questionnaire and not to interfere in the answers given by their peers. Administration of the PDFQ began with a researcher explaining its purpose and content by showing a poster size of each page of the questionnaire. The researcher encouraged pupils to think about the previous day with questions such as "Which day of the week was yesterday?", "Did you go to school yesterday?", "How did you go to school yesterday?", "Did you eat breakfast yesterday morning?", "Which foods or beverages illustrated on the page in front of you did you eat/drink for breakfast yesterday?". This set of questions was repeated for each meal illustrated in the questionnaire. The children were instructed to circle the item they had consumed for each meal on the previous day. Two researchers circulated through the classroom to respond to requests for help and to ensure that answers were legible, without interfering with the children's completing of the questionnaire. The children took approximately 40 minutes to complete the questionnaire. Data was collected from March to October 2007, covering all the days of the week except Friday. This strategy was used in order to describe the daily variability of food consumption including one day of the weekend allowing for the analysis of food consumption at the group level.

\section{Data analysis}

For each food, food group and beverage, the frequency of consumption (in times per day) was calculated by summing reported consumption over six daily eating events (e.g. the fruits and vegetables food group was calculated by adding reported consumption of fruits, fruit juices, starchy vegetables, vegetable soup and leafy vegetables over six eating events on the previous day). The frequency of consumption was also calculated for each main meal (breakfast, lunch and dinner) and snack (mid-morning, mid-afternoon and evening). The foods and beverages were categorized in ten groups on the basis of nutrient content in order to assess intake of recommended foods [positive indicators: milk and dairy products (milk, coffee with milk, chocolate flavoured milk, cheese, yoghurt), cereals (bread or crackers, rice, pasta), dry beans, meat (beef or poultry, fish and seafood), fruits and fruit juices, vegetables (leafy vegetables, starchy vegetables, vegetable soup), fruit and vegetables (including fruit juices)] or recommended in small quantities [sweets (lollypops, ice cream, cakes, biscuits)] by the Brazilian Food Guidelines (BFG) 15, and those that are discouraged [negative indicators: high fat salty snacks (French fries, pizza, hamburger sandwich, chips), soft drinks].

The BFG 15 is a food selection guide to help Brazilians choose a healthy diet using a variety of foods. The guide is based on five core food groups and recommends how many servings of these groups should be consumed daily. For example, it is recommended that sweet foods are consumed at most once a day, whereas fruit juice should be consumed at breakfast or in between the main meals. As these recommendations are not explicitly directed to any specific age group, they include children as well. As the BFG state their food recommendations in terms of servings per day, we assumed that each time a food was reported, the quantity was that of a serving. This assumption was necessary because we could not quantify the food illustrated in the questionnaire and because of the cognitive constraints of children at this age in recalling precise quantities of a food portion. As the BFG states the restriction of the consumption of soft drinks and high fat foods without specifying the quantities of servings per day, no consumption of these foods may be better represented in terms of compliance with the guidelines and with local school food policies. The compliance with the BFG in terms of recommended number of meals and snacks and the daily frequency of consumption of ten food groups was the main binary outcome measure. 


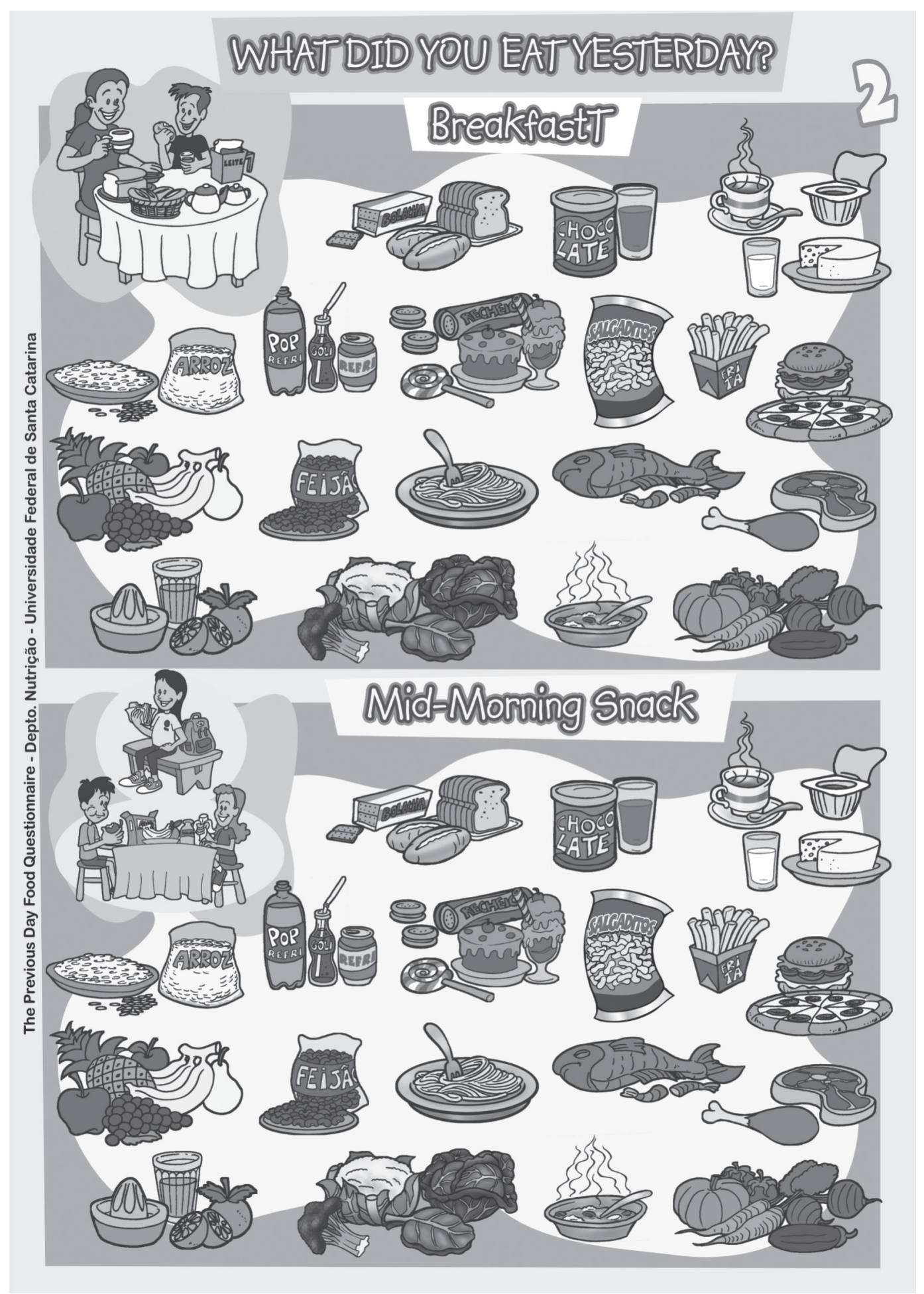


The proportions of children meeting the minimal recommendation for a specific food were compared between boys and girls and between public and private schools using Pearson's chi-square. The income effect for the compliance with the BFG, by type of school, was tested by logistic regression using compliance (yes/no) as the dependent variable and family monthly income as an independent variable [six levels with a linear increment of R\$ 500 (US\$ 269)].

A complex sample on SPSS version 15.0 (SPSS Inc., Chicago, USA) was used for the data analysis. The significance level was set at $\mathrm{p}<0.05$.

\section{Results}

Table 1 shows the demographic and socioeconomic characteristics of the study population by type of school. The sample included boys and girls with different monthly family incomes,

Table 1

Demographic and socioeconomic characteristics of the study population, by type of school $(\mathrm{N}=1,232)$.

\begin{tabular}{|c|c|c|}
\hline Variables & $\begin{array}{l}\text { Public school } \\
\quad(n=950)\end{array}$ & $\begin{array}{l}\text { Private school } \\
\qquad(n=282)\end{array}$ \\
\hline & $\%$ & $\%$ \\
\hline \multicolumn{3}{|l|}{ Sex } \\
\hline Boys & 48.3 & 54.9 \\
\hline Girls & 51.7 & 45.1 \\
\hline \multicolumn{3}{|l|}{ Age (years) } \\
\hline $7-7.9$ & 19.6 & 27.1 \\
\hline $8-8.9$ & 22.5 & 24.7 \\
\hline $9-9.9$ & 29.9 & 25.4 \\
\hline 10-10.9 & 28.0 & 22.8 \\
\hline \multicolumn{3}{|l|}{ School year } \\
\hline 2nd & 4.9 & 7.8 \\
\hline $3 r d$ & 29.6 & 14.7 \\
\hline $4^{\text {th }}$ & 28.6 & 27.1 \\
\hline $5^{\text {th }}$ & 24.6 & 25.1 \\
\hline $6^{\text {th }}$ & 12.2 & 18.6 \\
\hline 7th & 0.1 & 6.8 \\
\hline \multicolumn{3}{|c|}{ Monthly income $(\mathrm{R} \$)$ * } \\
\hline $100-500$ & 14.2 & 1.0 \\
\hline $501-1,000$ & 40.2 & 2.1 \\
\hline $1,001-1,500$ & 23.2 & 3.4 \\
\hline $1,501-2,000$ & 13.8 & 5.6 \\
\hline $2,001-2,500$ & 3.3 & 3.2 \\
\hline$>2,500$ & 5.3 & 84.8 \\
\hline
\end{tabular}

* U\$ $=\mathrm{R} \$ 1.86$ (September 2007 exchange rate). ages and schools grades. Mean age $( \pm$ SD) was higher for boys from public schools compared with those from private school $(9.1 \pm 1.1$ vs. $8.8 \pm$ $1.2 ; \mathrm{p}=0.002)$ but there was no statistically significant difference for girls $(9.1 \pm 1.1$ vs. $8.9 \pm 1.2$; $\mathrm{p}=0.101$ ), (data not shown). Attending private or public school was highly dependent on family income. Among children whose parents reported monthly income of up to R\$2,000 (US\$ 1,076), approximately $90 \%$ were from public schools. On the other end of the income distribution, approximately 4 out of 5 parents earning more than $\mathrm{R} \$ 2,500$ (US\$ 1,345) enrolled their children in a private school.

The proportions of children meeting the recommendations of the BFG for the principal food groups recommended, as well as for the number of main meals and snacks, are presented in Table 2. More than $50 \%$ of the children met recommendations for the dry beans, meat and sweets food groups, and for eating three main meals and two snacks. For the other food groups, this percentage ranged from around $6 \%$ for cereals and vegetables to $37.9 \%$ for milk and dairy products.

Seven percent of children did not meet any recommendations for the five core food groups of the BFG (milk and dairy products, cereals, dry beans, meat, fruits and vegetables) and only $2 \%$ met all the five recommendations. $50 \%$ and $56 \%$ of the children did not report consumption of fruits and vegetables, respectively (details not shown). More than half of children reported no consumption of high fat snacks (French fries, chips, pizza and hamburger), and only a third did not consume soft drinks, on the day prior to the administration of the questionnaire. Moreover, at least 1 in 3 schoolchildren reported consumption of soft drinks two or more times on the previous day (data not shown).

Children attending public schools were more likely than children from private schools to meet the recommendations for the milk and dairy products and meat food groups, as well as for eating three main meals and two snacks on the previous day. On the other hand, a higher proportion of children from private schools were in compliance with the BFG for the fruit food group compared to children from public schools (Table 2). In addition, a higher proportion of children from private schools did not meet any recommendations for the five core food groups compared to those from public schools ( $10 \%$ vs. $5.1 \%$; $\mathrm{p}=0.007$, details not shown). No differences were observed in consumption of high fat salty snacks and soft drinks reported by children from public versus private schools.

Statistically significant differences between boys and girls were found only for the consump- 
Percentage of schoolchildren meeting daily recommendations from the Brazilian Food Guidelines for the consumption of food groups, meals and snacks, according to their selection on the Previous Day Food Questionnaire, by type of school.

\begin{tabular}{|c|c|c|c|c|c|}
\hline \multirow[t]{3}{*}{ Food groups * } & \multirow{3}{*}{$\begin{array}{l}\text { Recommended } \\
\text { servings/day ** }\end{array}$} & \multicolumn{3}{|c|}{$\%$ meeting daily recommendations } & \multirow[t]{3}{*}{ p-value } \\
\hline & & $\begin{array}{l}\text { All children } \\
(n=1,232)\end{array}$ & $\begin{array}{l}\text { Public school } \\
\qquad(n=950)\end{array}$ & $\begin{array}{l}\text { Private school } \\
\qquad(n=282)\end{array}$ & \\
\hline & & $\%(95 \% \mathrm{Cl})$ & $\%(95 \% \mathrm{Cl})$ & $\%(95 \% \mathrm{Cl})$ & \\
\hline $\begin{array}{l}\text { Milk and dairy products (milk, } \\
\text { coffee with milk, chocolate milk, } \\
\text { yoghurt, cheese) }\end{array}$ & 3 & $37.9(33.4-42.6)$ & $41.9(36.2-47.8)$ & $30.9(25.5-36.9)$ & $0.01 * * *$ \\
\hline $\begin{array}{l}\text { Cereals (bread, crackers, rice, } \\
\text { pasta) }\end{array}$ & 6 & $6.5(5.0-8.4)$ & $7.3(5.5-9.8)$ & $5.1(2.4-10.4)$ & 0.3 \\
\hline Dry beans & 1 & $59.1(53.5-64.4)$ & $62.5(56.5-68.0)$ & $53.2(40.2-65.8)$ & 0.2 \\
\hline $\begin{array}{l}\text { Meat and fish (beef, poultry, fish } \\
\text { and sea foods) }\end{array}$ & 1 & $73.5(69.8-76.8)$ & $76.2(72.4-79.6)$ & $68.8(63.0-74.1)$ & $0.03^{* \star *}$ \\
\hline Fruits (including fruit juices) & 3 & $27.2(22.1-33.0)$ & $23.4(19.9-27.3)$ & $34.0(25.1-44.1)$ & $0.03 * \star \star$ \\
\hline $\begin{array}{l}\text { Vegetables (leafy, starchy } \\
\text { vegetables and soups) }\end{array}$ & 2 & $5.5(3.9-7.7)$ & $4.9(3.1-7.6)$ & $6.5(3.9-10.7)$ & 0.4 \\
\hline $\begin{array}{l}\text { Fruits and vegetables (including } \\
\text { fruit juice) }\end{array}$ & 5 & $15.0(12.3-18.1)$ & $13.0(10.7-15.9)$ & $18.3(13.6-24.2)$ & 0.1 \\
\hline $\begin{array}{l}\text { Sweets (lollypops, ice cream, cakes, } \\
\text { biscuits) }\end{array}$ & 1 & 78.7 (75.6-81.5) & $79.6(75.6-83.1)$ & $77.2(71.6-82.0)$ & 0.4 \\
\hline $\begin{array}{l}\text { Salty snacks (chips, French fries, } \\
\text { pizza, hamburger sandwich) }\end{array}$ & 0 & $58.1(51.8-64.2)$ & $55.4(49.8-60.9)$ & $62.8(51.8-72.7)$ & 0.2 \\
\hline Soft-drinks & 0 & 33.5 (27.7-39.8) & 30.9 (26.4-35.7) & $38.0(27.8-49.5)$ & 0.2 \\
\hline Meals and snacks *,\# & 3 meals and 2 snacks & $67.7(62.7-72.2)$ & $71.0(64.5-76.6)$ & $61.9(57.9-65.8)$ & $0.02 * * *$ \\
\hline
\end{tabular}

95\% Cl: 95\% confidence interval.

* Illustrated on the Previous Day Food Questionnaire version 3;

** Brazilian Food Guidelines;

*** Significant difference between children from public and private school;

\# Meals: breakfast, lunch and dinner; Snacks: mid-morning, mid-afternoon or evening snack.

tion of fruit and cereals. In public schools, a higher proportion of girls met the recommended consumption of fruits, whereas in private schools a higher proportion of boys reported consumption of the cereals in compliance with the guideline (details not shown).

The association between meeting the recommendations of the BFG and monthly family income is summarized in Table 3, by type of school. In public schools, on average, for each increase of R\$ 500 (U\$ 269) in monthly income, the odds of meeting the recommendations decreased for cooked beans (14\%), and fruit and vegetables food groups (18\%). In private schools, the increase in monthly family income showed a borderline effect on the decrease of meeting the recommendations for fruit and vegetables food groups $(\mathrm{p}=0.05)$.

\section{Discussion}

In this paper, we analyze to what extent the schoolchildren from Florianópolis meet the recommendations of the BFG 15 and local school food policies 14 , using the PDFQ on a representative sample of 7-10 year olds. The novelty of this approach is to evaluate the diets by comparing the recommendations with actual food intake instead of focusing on macronutrient dietary consumption. The latter is a traditional research paradigm which can be complemented by the former approach. The strengths and limitations of this approach are exemplified in light of the results presented.

The results indicated that a high percentage of children in the present study failed to meet the recommendations for various food groups and only $2 \%$ of children met the recommendations 
Odds ratio and $95 \%$ confidence intervals $(95 \% \mathrm{Cl})$ for the effect of monthly family income * on meeting the recommendations of Brazilian food guidelines for the food groups, meals and snacks selected by schoolchildren on the Previous Day Food Questionnaire, by type of school.

\begin{tabular}{|c|c|c|c|c|}
\hline \multirow[t]{2}{*}{ Food group } & \multicolumn{2}{|c|}{ Public schools $(n=950$ ) } & \multicolumn{2}{|c|}{ Private schools $(n=282)$} \\
\hline & OR $(95 \% \mathrm{Cl})$ * & p-value & OR $(95 \% \mathrm{Cl})$ * & p-value \\
\hline $\begin{array}{l}\text { Milk and dairy products (milk, coffee with milk, } \\
\text { chocolate milk, yoghurt, cheese) }\end{array}$ & $0.98(0.89-1.08)$ & 0.7 & $1.07(0.82-1.39)$ & 0.5 \\
\hline Cereals (bread, crackers, rice, pasta) & $0.77(0.52-1.13)$ & 0.2 & $0.75(0.52-1.07)$ & 0.1 \\
\hline Dry beans & $0.86(0.76-0.97)$ & 0.02 & $0.91(0.69-1.19)$ & 0.4 \\
\hline Meat and fish (beef, poultry, fish and sea foods) & $0.86(0.70-1.06)$ & 0.1 & $0.79(0.47-1.31)$ & 0.3 \\
\hline Fruits (including fruit juice) & $0.85(0.72-1.01)$ & 0.06 & $0.75(0.50-1.12)$ & 0.1 \\
\hline Vegetables (leafy, starchy vegetables and soups) & $0.83(0.58-1.18)$ & 0.2 & $0.92(0.51-1.66)$ & 0.7 \\
\hline Fruits and vegetables (including fruit juice) & $0.82(0.69-0.99)$ & 0.04 & $0.56(0.32-1.00)$ & 0.05 \\
\hline Sweets (lollypops, ice cream, cakes, chocolate) & $1.05(0.89-1.25)$ & 0.5 & $1.40(0.92-2.14)$ & 0.1 \\
\hline Three meals and two snacks ** & $0.93(0.79-1.08)$ & 0.3 & $0.90(0.64-1.25)$ & 0.4 \\
\hline
\end{tabular}

* Increase of R\$ 500 in monthly family income (R\$ $500=$ US\$269, September 2007 exchange rate);

** Meals: breakfast, lunch and dinner; Snacks: mid-morning, mid-afternoon or evening snack.

for all five core food groups. School type differences showed a significantly larger proportion of children from public schools meeting recommendations for milk/dairy products and meat/ fish groups compared to children in private schools. The children from public schools were more likely to meet the requirement for eating three main meals and two snacks despite the fact that they were from a lower social class background. On the other hand, children attending private schools had a significantly higher intake of fruits and a slightly higher intake of fruits and vegetables, although the latter difference was not statistically significant. We also found a negative relationship between monthly family income and compliance with the BFG for cooked beans, and fruit and vegetable food groups in public schools.

In Brazil, the school meal program (the Programa Nacional de Alimentação Escolar - PNAE) 5,20 plays a major role in the diet of school-aged children enrolled in public schools. Nearly all public schools are covered by the PNAE with one meal. In the city of Florianópolis, $80 \%$ of these schools offer two meals for children during their stay in the school. Nutritionists from the $\mathrm{Mu}$ nicipality or the State Departments monitor the nutritional quality of the meals children receive through the school meal programs.

Additionally, a high percentage of children in Florianópolis consumed salty snacks and soft drinks on the previous day, consistent with data reported previously for Brazilian adolescents 21,22 and from other countries 9,23,24. It is important to acknowledge that Florianópolis was the first Brazilian city that implemented the legislation prohibiting the sale of soft drinks and high-fat readyto-eat snacks in schools canteens. The evidence from the present analysis suggests that this policy has not been fully enforced. The reasons for such a state of affairs include inadequate control over the products sold in canteens and even more so outside the school environment where these products are easily obtainable. As children participating in the present study attend the school either in the morning or in the afternoon, there is plenty of time for children to buy them. This problem highlights the importance of promoting healthy eating behavior not only in school but also outside the school, including home and on-the-way-home environments. The evaluation of the adherence after seven years of legal regulation of the commercialization of soft drinks and high-fat ready-to-eat snacks in school canteens confirmed the reduction in commercialization of the prohibited food items. However, almost $61 \%$ of the establishments also sell artificial juices in detriment to fruits, which are rarely offered 25. Among American adolescents, a negative association was found between fast-food consumption (defined by the percentage of total calories contributed by fast food) and the odds of meeting the recommendations outlined in the MyPyramid Food Guidance System for milk (boys), fruits (girls), and vegetables and discretionary energy (boys and girls) 23 . 
The comparison of the results in the present study and those of other studies is limited because of the differences in study design, age of children, tools and methods for collecting data, and the definition of the food group consumption. In a study conducted in 1989-1991 with American youths aged 2-19, the percentages meeting national recommendations were based on the recommended number of servings from the USDA Food Guide Pyramid and ranged from around $30 \%$ for fruits, grains, meat, and dairy products to $36 \%$ for vegetables. 16 percent of young people did not meet any recommendations, and only $1 \%$ met all recommendations 24 . The data analysis of Australian children aged 2 to 18 years showed that more than one third did not eat any fruit and $20 \%$ did not eat any vegetables on the day prior to the interview 26 .

\section{Strengths and limitations of the PDFO}

The major strength of the PDFQ is that the instrument has been validated for schoolchildren. The assessment of food habits is the key issue for studies of the relation between diet and health, so it is of utmost importance that the dietary methods give an adequate measure of food intake. Furthermore, valid estimates of dietary intake are needed to inform policy decision making. The PDFQ is a practical and cost-effective method for such a purpose because it is easy to administrate in school settings. Our experience shows that it takes approximately 40 minutes for children to complete it as a supervised classroom exercise. The PDFQ can also be administered on various days of the week, allowing for an evaluation of the effectiveness of nutritional interventions. As the same 21 food items are illustrated in each of the six eating events included in the PDFQ, daily frequency and timing of food intake can easily be assessed through the profile of eating behavior during the day.

The main limitation of the PDFQ is that it was not designed to estimate nutrient intake. Therefore the questions about portion size and serving size, both of which could greatly contribute to a more detailed nutrient analysis, are not included. This avoids the difficulties associated with children's assessments of portion size 7, simplifying the memory task by prompting only the relevant food items eaten on the previous day. Like some questionnaires validated in other countries, this approach keeps the questionnaire relatively brief and easy for the child to complete with minimal assistance $8,9,27$. The cognitive task required for estimating portion size, frequency and averaging may not be compatible with the perceptual and conceptual capacities of children who have not reached the stage of abstract reasoning, at approximately 10-11 years of age 28,29,30. Parents may help in reporting their children' food intakes in the home but often do not know what their consumption is outside the home. More precise methods such as 24-hour recalls and food diaries are costly and put too much burden on the respondents, making them unpractical in a school setting 7 .

Because the frequency of food intake was estimated as times per day rather than by the number of servings as stated in the BFG, the PDFQ may underestimate the proportions of children meeting the guidelines, as we cannot know if items were eaten more than once at a time. In other words, the PDFQ assumes that only one serving is consumed on each occasion for all food items. In general, estimates of food and food group's intake from abbreviated questionnaires such as the PDFQ are lower than those from other methods of dietary assessment like multiple 24hour recalls or those that include food combinations (e.g., risotto, lasagna).

The food and food groups assessed by the PDFQ include only one day of eating behavior ("What did you eat yesterday?"). Recall data collected for one day for each individual is limited by the fact that a single day of intake may not be representative of usual individual intake. Day-today intake is highly variable for many individuals. Variations within individuals may be larger for foods consumed occasionally, such as vegetables, fish and specific meats, than for foods consumed daily, such as rice and beans. On the other hand, our results are strengthened by a reasonable sample size and good coverage of the days of the week, including one day of the weekend, as well as by representing both public and private schools.

Due to the limited scope of information covered by the questionnaire and the time constraints involved in its administration, only a limited number of relevant food items and meals could be illustrated in the questionnaire. The foods included were selected to reflect indicators of overall diet and current dietary guidelines, as well as to provide epidemiologic data for surveillance and planning purposes rather than to provide precise levels of nutrient intake at the individual level. Nevertheless, the PDFQ results are expected to reflect the intake of key nutrients and therefore present a moderate correlation with the instruments that estimate nutrient intake. For example, the amount of dietary calcium might be expected to be positively correlated with the intake of milk and dairy products; and the number of beans, vegetables and fruits might be expected to be positively correlated with the intake of di- 
etary fibers. It should be kept in mind that it is not necessary to have an estimate of nutrient intake for many community nutrition measures, since dietary recommendations are given in terms of food choices that make a healthy diet.

Recently, some novel statistical analyses have been proposed to analyze the data from the food frequency questionnaires such as the PDFQ. For example, the determination of the meal pattern is an important marker of eating behavior and lifestyle. As an individual diet involves a complex combination of various foods whose consumption is typically correlated, the differences in meal patterns can be identified for groups of people with a particular health problem 31,32. This approach may be more adequate for epidemiological studies investigating the relationships between nutritional factors and health, as it is particularly challenging to identify the effect of a specific food and/or nutrient on health. To investigate the effect of overall diet on chronic diseas- es, other studies have identified dietary patterns using factor analysis and/or cluster analysis or a more recent method called reduced rank regression 33,34

In conclusion, despite the fact that most of the children complied with the BFG regarding the consumption of meat/fish, dry beans, sweets, and eating 3 meals and 2 snacks, only $6.5 \%$ of the children met the recommendations for the cereals, and only $15 \%$ for the fruit and vegetables food groups. In addition, nearly half of the children reported the consumption of salty snacks and about two thirds consumed soft drinks on the previous day. The PDFQ was confirmed as a practical and cost-effective method for the evaluation of compliance with health promotion targets. For future research, we recommend training sessions with the classroom teacher and researchers in order to ensure the appropriate application of this instrument with schoolchildren.

\section{Resumo}

Avaliação qualitativa da dieta de uma amostra probabilística de escolares de 7-10 anos $(n=1.232)$ de Florianópolis, Santa Catarina, Brasil, é apresentada por meio de uma análise da concordância com as recomendações do guia alimentar para a população brasileira. Os aspectos positivos e as limitações do Questionário Alimentar do Dia Anterior (QUADA) são também discutidos. As freqüências de consumo foram definidas em vezes por dia que os grupos de alimentos foram relatados no QUADA. As porcentagens de escolares que atingiram as recomendações mínimas do guia e que consumiram alimentos não recomendados foram comparadas entre os sexos, tipo de escola (pública versus privada) e nível de salário familiar. A maioria das crianças apresentou concordância com o guia para o consumo de carnes/peixes, feijão, doces e realização de três refeições e dois lanches; somente 6,5\% atingiram as recomendações dos cereais e 15\% das frutas e hortaliças. O QUADA confirmou-se como um método prático e de custo-efetividade para a avaliação da concordância com metas de promoção de saúde.

Inquéritos sobre Dietas; Hábitos Alimentares; Questionários; Estudantes

\section{Contributors}

M. A. A. de Assis contributed to outlining the study, writing it up and data analysis. M. C. M. Calvo participated in the write up, statistical data analysis and interpretation of the results. E. Kupek was involved in outlining the study, data analysis and write up. F. A. G. Vasconcelos contributed to the study outline, write up and interpretation of results. M. Machado participated in the write up and interpretation of results. V. C. Campos helped to outline the study, write it up and interpret results. F. F. Costa contributed towards to the write up, data analysis and interpretation of results. D. F. Andrade participated in the write-up, statistical analysis of data and interpretation of results.

\section{Acknolwedgments}

We would like to thank the National Research Council (CNPq; process n. 402322/2005-3) for financial support of this project. 


\section{References}

1. Wang Y, Monteiro C, Popkin BM. Trends of obesity and underweight in older children and adolescents in the United States, Brazil, China and Russia. Am J Clin Nutr 2002; 75:971-7.

2. Levy-Costa RB, Sichieri R, Pontes NS, Monteiro CA: Household food availability in Brazil: distribution and trends (1974-2003). Rev Saúde Pública 2005; 39:530-40.

3. Malta D, Moura EC, Castro A, Cruz D, Morais Neto OL, Monteiro CA. Padrão de atividade física em adultos brasileiros: resultados de um inquérito por entrevistas telefônicas, 2006. Epidemiol Serv Saúde 2009; 18:7-16.

4. Ministério da Saúde. Dez passos para a promoção da alimentação saudável nas escolas. http://nutri cao.saude.gov.br/documentos/dez_passos_pas_ escolas.pdf (accessed on 25/Aug/2009).

5. Ministério da Saúde/Ministério da Educação. Portaria Interministerial $n^{\circ} .1 .010$, de 8 de maio de 2006. Institui as diretrizes para a Promoção da Alimentação Saudável nas Escolas de educação infantil, fundamental e nível médio das redes públicas e privadas, em âmbito nacional. http://ftp.fnde.gov. br/web/resolucoes_2006/por1010_08052006.pdf (accessed on 25/Aug/2009).

6. Ministério da Saúde. Regulamentação da comercialização de alimentos em escolas no brasil: experiências estaduais e municipais. http://nutricao. saude.gov.br/documentos/regula_comerc_alim escolas_exper_estaduais_municipais.pdf (accessed on 25/Aug/2009).

7. Livingstone MB, Robson PJ, Wallace JM. Issues in dietary intake assessment of children and adolescents. Br J Nutr 2004; 92 Suppl 2:S213-22.

8. Moore HJ, Ells LJ, McLure SA, Crooks S, Cumbor D, Summerbell CD, et al. The development and evaluation of a novel computer program to assess previous-day dietary and physical activity behaviours in school children: the Synchronised Nutrition and Activity Program (SNAP). Br J Nutr 2008; 99: 1266-74.

9. Magarey A, Golley R, Spurrier N, Goodwin E, Ong F. Reliability and validity of the Children's Dietary Questionnaire: a new tool to measure children's dietary patterns. Int J Pediatr Obes 2009; 4:257-65.

10. Barros MVG, Assis MAA, Pires MC, Grossemann S, Vasconcelos FAG, Luna MEP, et al. Validity of physical activity and food consumption questionnaire for children aged seven to ten years old. Rev Bras Saúde Matern Infant 2007; 7:437-48.

11. de Assis MA, Guimarães D, Calvo MC, Barros MV, Kupek E. Reproducibility and validity of a food consumption questionnaire for schoolchildren. Rev Saúde Pública 2007; 41:1054-7.

12. de Assis MAA, Kupek E, Guimarães D, Calvo MCM, Andrade DF, Bellisle F. Test-retest reliability and external validity of the Previous Day Food Questionnaire for 7- to 10-year-old school children. Appetite 2008; 51:187-93.

13. de Assis MA, Benedet J, Kerpel R, Vasconcelos FA, Di Pietro PF, Kupek E. Validation of the third version of the Previous Day Food Questionnaire (PDFQ-3) for 6-to-11-years-old schoolchildren. Cad Saúde Pública 2009; 25:1816-26.
14. Lei Estadual no. 12.061/2001. Dispõe sobre critérios de concessão de serviços de lanches e bebidas nas unidades educacionais, localizadas no Estado de Santa Catarina. Florianópolis: Ministério Público, Santa Catarina, 2001. http://www.mp.sc.gov. $\mathrm{br} / \mathrm{portal} / \mathrm{site} / \mathrm{portal} /$ portal_lista.asp? campo $=758$ (accessed on 25/Aug/2009).

15. Ministério da Saúde. Guia alimentar para a população brasileira. Brasília: Ministério da Saúde. http:/ / www.saude.gov.br (accessed on 25/Aug/2009).

16. Ministério da Saúde. Informações de saúde. População residente - Santa Catarina, 2009. http:// tabnet.datasus.gov.br/cgi/tabcgi.exe?ibge/cnv/ popsc.def (accessed on 28/Aug/2009).

17. Secretaria Municipal da Saúde. Caderno de informações de saúde. Tábua de sobrevivência - esperança de vida. Florianópolis, 2007. http://www. pmf.sc.gov.br/saude (accessed on 28/Aug/2009).

18. Secretaria Municipal da Saúde. Indicadores saúde da criança - Santa Catarina. Taxa de mortalidade $<1$ ano segundo município. Florianópolis, 2007. http://www.saude.sc.gov.br/cgi/tabcgi.exe?IndCri/ IndCri.def (accessed on 28/Ago/2009).

19. de Assis MA, Rolland-Cachera MF, Grosseman S, Vasconcelos FA, Luna ME, Calvo MC, et al. Obesity, overweight and thinness in schoolchildren of the city of Florianópolis, Southern Brazil. Eur J Clin Nutr 2005; 59:1015-21.

20. Fundo Nacional de Desenvolvimento da Educação. Resolução/FNDE/CD no. 32 de 10 de agosto de 2006. Estabelece as normas para a execução do Programa Nacional de Alimentação Escolar PNAE. Brasília: FNDE, 2006. ftp://ftp.fnde.gov.br/ web/resolucoes_2006/res032_10082006.pdf (accessed on 25/Aug/2009).

21. Castro IR, Cardoso LO, Engstrom EM, Levy RB, Monteiro CA. Vigilância de fatores de risco para doenças não transmissíveis entre adolescentes: a experiência da cidade do Rio de Janeiro, Brasil. Cad Saúde Pública 2008; 24:2279-88.

22. Sichieri R, Paula Trotte A, Souza RA, Veiga GV. School randomised trial on prevention of excessive weight gain by discouraging students from drinking sodas. Public Health Nutr 2009; 12:197202.

23. Sebastian RS, Wilkinson Enns C, Goldman JD. US adolescents and My Pyramid: associations between fast-food consumption and lower likelihood of meeting recommendations. J Am Diet Assoc 2009; 109:226-35.

24. Muñoz KA, Krebs-Smith SM, Ballard-Barbash R, Cleveland LE. Food intakes of US children and adolescents compared with recommendations. Pediatrics 1997; 100(3 Pt 1): 323-9.

25. Gabriel CG, Vasconcelos FA, Andrade DF, Schmitz BA. First law regulating school canteens in Brazil: evaluation after seven years of implementation. Arch Latinoam Nutr 2009; 59:128-38.

26. Magarey A, Daniels LA, Smith A. Fruit and veg etable intakes of Australians aged 2-18 years: an evaluation of the 1995 National Nutrition Survey data. Aust N Z J Public Health 2001; 25:155-61. 
27. Edmunds LD, Ziebland S. Development and validation of the day in the life questionnaire (DILQ) as a measure of fruit and vegetable questionnaire for 7-9 year olds. Health Educ Res 2002; 17:211-20.

28. Baranowski T, Domel SB. A cognitive model of children's reporting of food intake. Am J Clin Nutr 1994; 59 Suppl:212S-7S.

29. Moore GF, Tapper K, Moore L, Murphy S. Cognitive, behavioral, and social factors are associated with bias in dietary questionnaire self-reports by schoolchildren aged 9 to 11 years. J Am Diet Assoc 2008; 108:1865-73.

30. Foster E, Adamson AJ, Anderson AS, Barton KL, Wrieden WL. Estimation of portion size in children's dietary assessment: lessons learnt. Eur J Clin Nutr 2009; 63 Suppl 1:S45-9.
31. Prochnik-Estima CC, Costa RS, Sichieri R, Pereira RA, Veiga GV. Meal consumption patterns and anthropometric measurements in adolescents from a low socioeconomic neighborhood in the metropolitan area of Rio de Janeiro, Brazil. Appetite 2009; 52:735-9.

32. Sjöberg A, Hulthén L. Assessment of habitual meal pattern and intake of foods, energy and nutrients in Swedish adolescent girls: comparison of diet history with 7-day record. Eur J Clin Nutr 2004; 58:1181-9.

33. Hoffmann K, Schulze MB, Schienkiewitz A, Nothlings $\mathrm{U}$, Boeing $\mathrm{H}$. Application of a new statistical method to derive dietary patterns in nutritional epidemiology. Am J Epidemiol 2004; 159:935-44.

34. Newby PK, Tucker KL. Empirically derived eating patterns using factor or cluster analysis: a review. Nutr Rev 2004; 62:177-203.

Submited on 31/Aug/2009

Final version resubmited on 02/Mar/2010

Approved on 09/Mar/2010 